\title{
A critical approach to the development of blended medical communication training materials ${ }^{1}$
}

\author{
Kris Van de Poel and Christine Fourie \\ Department of Linguistics, Applied Language Studies, Universiteit Antwerpen, Belgium | Centre for Academic \\ and Professional Language Practice - School of Languages, North-West University, South Africa \\ E-mail: kris.vandepoel@ua.ac.be
}

\begin{abstract}
Effective communication between doctors and patients improves patient health outcomes (Hewett et al. 2009; Stewart 1995; Watson et al. 2012), and communication skills courses have become an integrated component of the medical curriculum. However, language-discordant contexts are not fully provided for yet, since "[1] anguage support guides (such as the CalgaryCambridge guides; Silverman et al. 2005) generally target native speakers rather than language learners, and typically mention the use of a second or foreign language as just one of many issues in cross-cultural communication without providing any solutions or prescriptions to address ensuing communication problems" (Gasiorek and Van de Poel 2012:372). In a South African professional healthcare context, communication challenges are manifold because of the number of languages and cultures involved and because of the diverse views on the nature of a medical encounter. South African public healthcare is further hampered by a lack of doctors (KZN Department of Health 2013). Given the need for tailored communication materials, a new vocational training course in Afrikaans as a second language was introduced for first-year medical students at one South African university applying a blended learning approach (i.e. restricted contact teaching and autonomous online learning). To facilitate the development and implementation process, the European project Medics on the Move (MoM) was adapted and adopted as a communication tool. This paper addresses principles and practices underlying the MoM materials as part of the process of adapting the vocational training concept to the specific South African context, needs and learners. The development process is presented as an integral part of a comprehensive needs analysis (Brown 1995), at the end of which new questions and needs are identified. The results corroborate that MoM-SA is a dynamic and effective teaching/ learning tool which functions as a language support system that helps build skills for a multilingual professional environment.
\end{abstract}

Keywords: medical communication, vocational training, autonomous online learning, language support system, needs analysis

\footnotetext{
${ }^{1}$ We are grateful to Jessica Gasiorek from the University of Hawai'i for her valuable comments and contributions to this text.
} 


\section{Introduction}

\subsection{Medical communication challenges in South Africa}

Research has shown that the quality of doctor-patient and doctor-colleague communication directly influences the quality of patient care (see Hewett et al. 2009, Watson et al. 2012 for examples). Moreover, effective physician-patient communication significantly improves patient health outcomes (Stewart 1995:1423). Inspired by these findings, communication training worldwide has become an integrated component of the medical curriculum. However, language-discordant communication in which doctors and patients have different cultural backgrounds has not yet been fully integrated into the agenda and language support guides (such as the Calgary-Cambridge guides; Silverman et al. 2005) "typically mention the use of a second or foreign language as just one of many issues in cross-cultural communication without providing any solutions or prescriptions to address ensuing communication problems" (Gasiorek and Van de Poel 2012:372). Nevertheless, in contexts where medical professionals are in contact with different languages and cultures, i.e. where language-discordant and multicultural encounters are the order of the day, special attention should be paid to the professionals' communication training.

In a South African (SA) professional healthcare context, communication challenges are manifold, first and foremost because of the number of languages involved and because of diverse views on the nature of the medical encounter. Although not all 11 official languages are used equally frequently in professional contexts, medical professionals are recurrently "on the move" between languages and culture. Moreover, they have to adapt to different medical contexts and approaches and have to understand often conflicting, culturally-determined ideas, concerns and expectations. SA public healthcare is further hampered by an underrepresentation of doctors, with on average one doctor for every 4219 inhabitants (KZN Department of Health 2013).

Given these challenges, in 2012-2013 the Faculty of Medicine and Health Sciences at Stellenbosch University, in collaboration with the Language Centre and the Medics on the Move (MoM) team ${ }^{2}$, redesigned the existing communication training programme in Afrikaans as a second language for first-year medical students. The new programme adopted a blended learning approach consisting of (limited) contact teaching (20 hours) and autonomous online learning (20 hours). To facilitate the development and implementation process, the European $\mathrm{MoM}^{3}$ was adapted and adopted and renamed MoM-SA. MoM as well as MoM-SA are meant for (pre-)professionals to use autonomously as a communication tool in clinical settings, but they can also be used as a learning tool in training and teaching contexts ${ }^{4}$.

\footnotetext{
${ }^{2}$ The South African MoM-team is led by Kris Van de Poel and Tobie van Dyk. The project is undertaken with financial support from ICELDA and the research unit for Applied Language Studies at the University of Antwerp in Belgium.

${ }^{3}$ The development of the original MoM syllabus started in 2006 as an EU-co-funded project and has since developed into an online/mobile tool for medical communication in six European languages (Danish, Dutch, English, German, Italian and Swedish) at beginner and advanced levels, with translation support for six other languages (Arabic, French, Polish, Romanian, Russian and Turkish) (www.medicsmove.eu).

${ }^{4}$ In 2010-2011, teaching and coaching with MoM materials were piloted in Sweden and Denmark as part of MoM evaluation. The materials have been continuously evaluated since 2007 and are accessible on www.medicsmove.eu.
} 


\subsection{Programme foundations}

Given the specificities of the SA vocational training context as outlined above, it was necessary to systematically reflect on:

1. The nature of a professional communication policy and how it should be embedded in the curriculum to reflect internationally-validated and locally viable political, sociopsychological and teaching trends;

2. The required level of planning and how it should translate as a syllabus or backbone of the envisaged teaching and training programme, and

3. Reliable practice and principles and how they should fuel the course content, materials and methodology or approach.

For MoM-SA, this means that the communication-training programme has to reflect the curricular foundations of the Faculty of Medicine and Health Sciences. Therefore, the general medical orientation is patient-centred, an approach common in the West, and thus considers not only the doctor's perspective but also the patient's (Mishler 1984, Campion et al. 1992, Epstein 2000). In other words, this approach discusses and understands a condition both within a disease framework and an illness framework (Levenstein et al. 1989, Silverman et al. 2005, Stewart et al. 2003, Tate 2007). A second characteristic is that the communication strand - supporting the university's multilingual education policy and plan (Stellenbosch University 2004 and 2010) is firmly embedded in the medical curriculum and is gradually built up across the different years of study (Universiteit Stellenbosch, Fakulteit Geneeskunde en Gesondheidswetenskappe 2008) as communication is one of the five curricular foundations. In teaching, medical communication skills are the central focus of attention, and they should preferably be addressed and trained in authentic contexts, i.e. contexts that realistically reflect the students' later professional contexts. A large number of universities have therefore established communication skills labs as part of a set of multidisciplinary educational resources at healthcare students' disposal to enhance their clinical skills training. Finally, because quite a number of medical course programmes suffer from being overloaded, a blended learning approach is being adopted; this relatively new approach that "combine[s] face-to-face instruction with computer-mediated instruction" (Graham 2006:5) fosters the learners' autonomy and makes them co-owners of the teaching and learning process.

MoM is inspired by what the users need and want to learn based on linguistic, psychological and educational assumptions. The communicative needs of the MoM users have been established through an in-depth analysis of a representative sample of the target group and observations by supervisors and trainers (Gasiorek and Van de Poel 2012). MoM research has established that language-discordant medical professionals are often not aware of how to appropriately engage in medical communication. Linguistically, language-discordant doctors mainly experience problems on the level of modality and politeness in patient-doctor interactions (Van de Poel and Brunfaut 2010). Culturally, quite a large number of respondents claim to feel insecure when engaged in social interactions with superiors or in situations where face threat is involved (Gasiorek and Van de Poel 2012). Therefore, MoM aims to facilitate cross-cultural communication (even when using a lingua franca) and to enhance delicate patient-doctor relationships, as well as general professional medical interactions between colleagues. 
The communicative skills addressed in MoM are primarily speaking (oral communication) and listening (understanding or aural communication). However, medical communication does not function at a verbal (words) level only; non-verbal or paralinguistic information like eye contact, smiles and nods have been integrated in short authentic and contextualised scenarios. The scenarios follow the patient-doctor consultation timeline or can be situated in administrative and social contexts with colleagues or administrative staff.

MoM also takes into account the learning preferences and customs of the target audience. Medical professionals are used to a theoretically-founded analytical approach relying on metalanguage. However, since MoM in principle is an online, autonomous, on-the-job learning tool, a clear and unambiguous format was chosen in favour of elaborate theoretical explanations in hyperlinks or pop-ups. After all, the aim is to enhance professional communication.

\section{MoM-SA}

\subsection{Aim of the study}

In this article, we present the principles and practice underlying MoM-SA materials as an online and blended learning tool. We further look at how the design was implemented in the SA vocational context both for online learning and contact teaching (with new pen-and-paper materials) and how it was evaluated by the end users. Since MoM-SA is in its pilot phase, we will allow for some impressionistic reflections by the lecturer too. In doing so, we will not merely report on the process of syllabus development for SA implementation, but embed the discussion in a wider context where syllabus design is systematically fed with reflections from needs analysis, development of material and approach, testing, teaching and learning and programme evaluation.

We start from the premise that the quality of the medical communication tool has to meet the expectations of stakeholders (hospitals, management, lecturers, teachers) and beneficiaries ((pre-)professionals). Weideman (2013) states that "[i]f there is any lesson to be learned from failed language policies, plans and strategies, such as those at some nominally multilingual South African universities, it must be that there must be sufficient participation by those who will be affected, which in turn means that the accessibility of information and the accountability of the language management solution proposed are crucial". Thus, the needs analysis includes an evaluation of the product as well as the process, and the outcomes will be used to motivate the stakeholders to adapt the programme to new challenges and incentives (Brown 1995). Below we will elaborate on the features of good practice and principles while describing the programme in more detail.

\subsection{Methodology: A comprehensive needs analysis}

In order to generate a systematic and "defensible" programme (Brown 1995:86), we collected different types of data. First, a context analysis was carried out. On the basis of the available documents regarding curriculum, language, programmes, courses and teaching guides, intensive discussions were held with as many stakeholders as possible, such as faculty members responsible for medical communication training, the director of the Language Centre, lecturers and material developers. Students' perceptions and evaluations were taken into account, as well as the university's request for methodological adaptations and incorporation of new online 
media. Since the development process also has to be feasible, an inventory of existing materials was made and mapped onto the programme's objectives before it was decided what materials to adopt for the teaching component, what to adapt, and what to develop. One of the most important considerations in design (see Weideman 2013) is the programme's face validity. Consideration of this issue led to the collection of objective and subjective data to determine the beneficiaries' needs, wants and wishes (Van de Poel and Gasiorek in press, Van de Poel, Seberechts and Fourie 2013).

In 2013, there was a pilot phase of three months during which the materials were used by a group of 30 first-year medical students. During this phase, the needs analysis was substantiated with test results that present a longitudinal and process picture of students' communication development (see section 4.1 below). The test data were collected through a validated placement test of academic literacy (TAG/TALL; Weideman 2003), an aptitude test (modelled on Carroll and Sapon's (2002) Modern Language Aptitude Test, and described in Van de Poel 1995), short diagnostic mid-term tests (after one month of instruction and learning) and a final achievement test. On the basis of beginning and end scores, the students' and the group's learning gains were calculated. These data complemented each other and provided a comprehensive profile of the group.

At the end of the course, a usability study was carried out in which the medical students evaluated MoM-SA in terms of its relevance, efficiency, impact, sufficiency and support (see section 4.2 for the results). The MoM-SA logframe model (initially developed by Entente UK (2008) and reported upon in Van de Poel 2011) makes use of matrix questions where respondents have to indicate the extent to which they agree with a range of statements on a fourpoint Likert scale (indicators are: $1=$ disagree entirely; $2=$ mostly disagree; $3=$ mostly agree; $4=$ agree entirely). At the end of the survey (see section 4.2 below for the closed section of the questionnaire), participants were given the opportunity to provide narrative comments. Structured prompts were provided in order to facilitate the comparative analysis. Example items included: what I liked about the course book, MoM online and the lessons; what I would like to see changed about the course (lessons, method and approach); etc. The evaluation data were collected to gain insights into the learners' experience of the materials and teaching/learning approach.

The data collection was concluded with some impressionistic reflections from the lecturer, collected while the new materials and approach were piloted (see section 4.3). Thus, in effect we carried out a 360-degree needs analysis which took place before, during and at the end of the first pilot with the aim of generating evaluation data from as many stakeholders as possible to be used as input for further material and method adaptations.

\section{Material development: From MoM to MoM-SA}

\subsection{The process of adopting and adapting}

At the end of 2012, the existing MoM materials were transferred to an SA context for online and contact teaching and learning in Afrikaans with a team of developers, pedagogues, 
technicians and medical consultants 5 . The initial focus was on adapting the content linguistically and culturally to Afrikaans and incorporating learning activities which were known and liked by the target audience. These activities were decided upon through elaborated semi-structured interviews with experienced language trainers who are familiar with the target group. On the basis of the interviews, the following impressionistic profile of students as language learners was drawn up: the students are intelligent, focused on their vocation, motivated and ambitious, and relatively aware of the need for good communication skills in their professional context. They think analytically and expect course objectives and outcomes to be explained, and to be told why, for instance, certain types of listening are used in certain medical encounters or why imperatives and politeness markers are used when examining patients. First-year medical students like to read newspaper articles, listen to songs, talk about cartoons, and play games as long as the underlying expectations of learning gain are met. In sum, face validity is important and language learning has to take place in as authentic a medical context as possible.

Having established all the elements to take into account, material development began. Since the materials had to fulfil a variety of contextual needs - South African, vocational training, second/foreign language learners and medical communication skills - and in order to promote online learning, MoM components were adopted (e.g. the syllabus) or adapted (e.g. the grammar) as the communication tools for learning and new elements were developed (e.g. the course book). In the following paragraphs, we will describe how the different components were incorporated in the course programme.

\subsection{MoM-SA content}

The MoM-syllabus is functional and relies on the doctor-patient consultation timeline, but it also consists of encounters between colleagues. The syllabus consists of 10 units with four training modules each and a library with reference materials. Not all materials are available in print as well as online.

Each unit is structured in a similar way so as to facilitate learning. The 10 units cover the following topics:

Table 1. Overview of topics in MoM English and MoM Afrikaans for basic users

- Greeting and saying goodbye

- Examining and instructing

- History-taking

- Symptom analysis

- Case presentation

- Emotions

- Explaining results

- The management plan

- Planning

- Problem solving
- Groet en afskeid neem

- Kliniese ondersoek

- Mediese agtergrond

- Simptoom-analise

- 'n Mediese verslag aanbied

- Emosies

- Resultate bespreek

- Behandelingsplan

- Beplanning

- Probleemoplossing

\footnotetext{
${ }^{5}$ Christine Fourie developed MoM-SA with support from Jackie van Wyk and Ria Swanepoel. The medical experts who consulted on the content were Aziza Bawoodien and Eddy Vanagt. The artwork was done by John W.N. Ross.
} 
Each unit contains several scenarios which were translated into Afrikaans. The developer relied significantly on the Dutch MoM-text (with its similarity in grammar and vocabulary), but the English text was also consulted for reference. The gradually increasing complexity of the Dutch syllabus from scenario to scenario was mirrored to a large extent in the Afrikaans version and Afrikaans-specific differences in grammar, like the double negation (nie ... nie), were incorporated. The context of the scenarios was then transformed to an SA setting, for example by using SA place names such as Gauteng, Mpumalanga and Kaapstad, and SA names and surnames such as Sipho, Fourie, Kamoetie and Le Roux. Finally, socio-cultural elements were incorporated (e.g. politeness elements or regional differences).

With the scenarios, the grammar, phonetics and word lists were developed and used as online reference tools (the library). The printed equivalents were grammar books (Van Dyk and Van de Poel 2013) and communication manuals (Van de Poel 2013).

In the next phase, the different training modules were adapted. They consisted of exercises on different linguistic items. An example of how the exercises diverged across the three languages can be seen in the following, where Afrikaans and Dutch speakers use the formal pronoun ' $u$ ' which is absent in English, and where Dutch and English distinguish between a personal and possessive form of the pronoun, but Afrikaans does not (Unit 1):

Table 2. Example of how exercises diverge across three languages

\begin{tabular}{|c|c|c|}
\hline $\begin{array}{l}\text { AFRIKAANS } \\
\text { Voltooi: } \text { u of }- \text { ? } \\
\text { Luister. } \\
\text { Wil ... sit? } \\
\text { Dankie ..... } \\
\text { Is ...... die nuwe dokter? Is } \\
\ldots . \text { nuut? } \\
\text { Verskoon my, ek het nie..... } \\
\text { naam gehoor nie. Kan .... dit } \\
\text { herhaal, ..... asseblief? Kan } \\
\ldots \ldots \text { dit vir my spel? } \\
\text { Waar kom ...... vandaan? } \\
\text { Waarin ....... spesialiseer } \\
\ldots . ?\end{array}$ & $\begin{array}{l}\text { NEDERLANDS } \\
\text { 'U' of 'uw'? } \\
\text { Luister. } \\
\text { Gaat ...... zitten. } \\
\text { Dank ....... . . de nieuwe } \\
\text { Bent ...... de nent nieuw? } \\
\text { dokter? ....... bent } \\
\text { Excuseer, ik heb ..... naam } \\
\text { niet gehoord. Kunt ...... } \\
\text { dat herhalen, alstublieft? } \\
\text { Kunt ....... dat voor me } \\
\text { spellen? } \\
\text { Waar } \\
\ldots \ldots . . . \text { vandaan? Wat is } \\
\text {.........specialisatie? }\end{array}$ & $\begin{array}{l}\text { ENGLISH } \\
\text { 'You' or 'your'? } \\
\text { Listen for the correct } \\
\text { answer. } \\
\text { Are ........ the new doctor? } \\
\text { Nice to meet ...... } \\
\text { What's } \\
\text { specialisation? } \\
\text { Excuse me, what's ........ } \\
\text { name? } \\
\text { Could ... repeat that for me } \\
\text { please? } \\
\text { Could ...... spell that for } \\
\text { me? } \\
\text { Where do ........ come } \\
\text { from? }\end{array}$ \\
\hline
\end{tabular}

\subsection{The linguistic approach}

Throughout the 10 units, the building blocks of the language are systematically introduced and studied. Each unit builds on the previous one and contains medical scenario texts with online audio and translations, as well as four training modules (exercises with corrections and online feedback). The modules take a bottom-up approach from phonemes to word formation and meaning to sentence structure and medical communication. In the first module, the student practises new sounds in isolation, in contrast and in context. Online, the sounds are linked to 
videos of sound production and inventories of medical words per sound in the library. In the second module, new vocabulary is practised. Most new words are presented in interactive word families (wordmaps) and online they are linked to a glossary with explanations, audio and translation (also accessible through the library). In the new grammar module, the learner is provided with an overview of the new language structures and items relevant for the unit which, in turn, links to a descriptive grammar in the library. Finally, the last training module deals with communication and provides the student with a platform to practise communication skills and links up to an online communication manual (in English only).

After developing and transferring the online materials from a European to an SA context, the learning materials were adapted for contact teaching. Since this is a new component to MoM, considerable time was spent on this developmental phase. The MoM-SA course book closely follows the online learning materials, but the selection of materials is adapted to classroom interaction. It is formatted as a work book with illustrations and drawings. Each unit begins with an overview and includes space for students to make notes about their expectations and objectives for the unit. The course book also contains exercises that are not found online. These exercises are designed to be more open, addressing issues that do not always have clear-cut "correct" answers, such as differences between colloquial language use and more formal language use.

The printed grammar is a reference guide that contains an overview of Afrikaans grammar (Van Dyk and Van de Poel 2013). Full explanations of rules and exceptions are provided in Afrikaans with short, easy-to-understand summaries in English. All the examples make use of medical vocabulary and refer to medical scenarios. For example, the following discusses how to use adjectives (13):

Die adjektief beskryf substantiewe en pronomina. Dit gee dus meer inligting oor die substantief of die pronomen. Adjektiewe kan attributief gebruik word (voor die substantief) of predikatief (ná die substantief).

Die dokter gebruik 'n klein stukkie watte om die wond te ontsmet.

Die stukkie watte wat die dokter gebruik om die wond te ontsmet, is klein.

$\rightarrow$ Adjectives describe (pro)nouns. They can occur before (attributive) or after (predicative) a noun. ...

Both the course book and the grammar book were used as part of the MoM-SA pilot course. The grammar book was used as a reference when students asked specific questions regarding, for example, spelling, plurals and tenses. The English summaries served not only as translations for students with very little or no proficiency in Afrikaans, but often also as introductions to grammar concepts in English, especially for English second-language students.

Follow-up assignments, similar to what was done in class, were posted on the university's learning space (Webstudies-Blackboard) for students to complete as homework. These tasks also required students to complete specific exercises online. The following is an example from Unit 1 on greeting and saying farewell: 
There are many ways in which you can greet people.

Go to online MoM-SA Unit 1 and study the wordmaps on greeting and politeness.

Imagine you are welcomed in hospital by the head of department. What would you say?

Record your introduction of yourself on your cellphone and make notes of words to remember in your Webstudies logbook.

Bring your recorded greeting to class.

In sum, the following materials were made available to the learners and lecturer:

Table 3. Inventory of materials available online and for teaching purposes

\author{
Afrikaans Basic \\ Online materials \\ Units 1-10: \\ -Scenarios \\ Training modules: \\ -Sound \\ - Meaning \\ -Wordmaps \\ -Form \\ -Communication \\ Library: \\ -Phonetics \\ - Glossary \\ - Grammar \\ - Communication manual \\ Helpline: \\ - How to use \\ -How to learn
}

\section{| Teaching materials}

$\mid \cdot$ Course book and teacher manual (authentic materials)

- Teacher manual
-Course book
-Course book
-Course book
-Course book and Webstudies-Blackboard

$\cdot$-Grammar book
-[online interactive resource only]
- Grammar book
-Communication skills

-Introduction to course book and grammar

-Introduction and awareness-raising at the beginning of each chapter in the course book

\subsection{The pedagogical approach}

A blended approach to learning and teaching was adopted. In this case, the student course book, lecturer's guide and grammar book were introduced as part of the programme, but students were also given the option to engage in (autonomous) online learning via the MoM-SA learning space. This presents the learners with the freedom to choose the material and learning route, as well as follow preferred learning routines. The approach enables just-in-time learning along three dimensions: learner-control, time-independent access and place-independent access (Riel 1998). Thus, the MoM-SA tool provides a platform for systematic and gradual learning in which the learner has the option to work through course materials that gradually become more complicated, but with enough repetition and examples to reinforce what has been learned. However, the learner can also pick what is needed at a particular moment. The pedagogy underlying the course is task-based and realistically reflects the activities to be undertaken in a medical context. 
After having developed the materials for the SA blended learning context, the materials were piloted and evaluated.

\section{Course programme evaluation}

The MoM-SA materials, as described above, were used for the first time from February to April 2013 with a group of 30 first-year medical students, most of whom were at a beginner level in terms of Afrikaans proficiency (only two of the students were not SA citizens).

\subsection{Learning gain}

All first-year medical students completed a (written and oral) placement test ${ }^{6}$ on the basis of which two groups were distinguished. The beginners $(n=30$; our focus of attention) also completed a pre-test which functioned as an aptitude test and was intended to give the lecturer an indication of grammatical knowledge, linguistic ability, linguistic skills, creativity in language learning, problem-solving ability and analytical skills, and was primarily used for remedial coaching in class. After one month, students sat two short diagnostic tests evaluating their progress (short-term achievement).

During the 20 contact hours, a variety of materials was used, including the course book, grammar book and external didactic materials like newspaper articles, pictures of skeletons, games and songs. In the middle of the term, one hour was spent on introducing the online materials in a computer classroom ${ }^{7}$. However, reference was made to online materials throughout the course. At the end of the course, the students took part in a series of short achievement tests (primarily testing communicative and oral skills as well as semantic fields predominantly used in medical settings).

The students' learning gain ${ }^{8}$ was first calculated using placement and achievement scores (LHUP 2013). The average learning gain for the entire class $(n=24$ because some students were absent at one of the test sessions) was $68 \%$ (and ranged between $56 \%$ and $89 \%$ ). Given the fact that most students were beginners in Afrikaans and the gain score was expected to be high, we also calculated the gain from the first diagnostic tests (after one month or approximately eight hours of teaching) until the final achievement tests (after 20 hours of teaching). This gain score ranged between $3 \%$ and $56 \%$, with a group mean of $33 \%(n=30$; no students absent). It should be noted that the students who did well on their English placement test generally scored well on the final test (better than those who scored well on the Afrikaans placement test; note that the students study in an English medium). Given the different natures of the tests (placement vs. achievement and diagnostic vs. achievement), these data have to be approached with caution. Both developers and lecturers were more interested in how students

\footnotetext{
${ }^{6}$ See Weideman (2003) on the placement test of academic literacy both in English (TALL) and Afrikaans (TAG).

${ }^{7}$ It must be noted that, by then, some students had forgotten their passwords and it showed that some of them still lacked computer literacy skills.

${ }^{8}$ A learning gain score is calculated for each individual student. Every student's gain score is the basis for calculating the average gain score for the entire class. The formula (using percentages) is as follows: (Postassessment - Pre-assessment) divided by (100\% - Pre-assessment). The actual gain (numerator) is divided by the potential gain (denominator). In this, one calculates how much the student gained out of the total possible amount that they could have gained from pre- to post-assessment, where pre-assessment is the percentage correct on preunit assessment and post-assessment is the percentage correct on post-unit assessment (LHUP 2013).
} 
perceived their own learning and how motivated they were to continue growing as future medical professionals.

\subsection{Usability study: Satisfaction and well-being}

In order to acquire insight into the learning experiences of the students, a written evaluation was carried out after the final contact session'. The evaluation process used a logic framework similar to that recommended by the EU for external intervention projects. First, the students graded 34 statements on a four-point scale $(1=$ strongly disagree; $4=$ strongly agree $)$ grouped according to the different course components (online, class, approach and outcome) and then they were prompted to provide narrative comments on the same components. The data can be grouped in different ways to acquire insight into different aspects of learning. First, we will briefly discuss the course outcome, and then we will regroup the questions to examine usability in more detail.

When we look at how the linguistic outcome at the end of the course was evaluated, overall, the students were very positive. On average, all of the following scored highly: students indicated that their ability to understand spoken Afrikaans $(M=3.76)$ and use it $(M=3.16)$ had improved, and that their vocabulary $(\mathrm{M}=3.72)$ and medical vocabulary had also improved $(\mathrm{M}$ $=3.23)$. They also stated that their understanding of language structures $(\mathrm{M}=3.00)$ had improved as well as their communication skills $(M=2.93)$. Lastly, they indicated that they felt more comfortable with medical Afrikaans $(\mathrm{M}=2.89)$. The fact that there was some disparity between the learners' evaluation of receptive and productive skills (e.g. understanding vs. use) and between general and occupational language use (e.g. general vs. medical vocabulary) shows that they realistically interpreted their own learning and future professional language use. These scores indicate that the majority of students felt the programme was relevant to their needs.

In order for the stakeholders to study the programme's usability in more detail, the statements have been regrouped according to the different evaluation criteria, namely support, impact, relevance, sufficiency and efficiency (see Table 4), and mean scores have been calculated.

\footnotetext{
${ }^{9}$ The original questionnaire can be obtained from the authors.
} 
Table 4. End users' evaluation of the support, impact, relevance, sufficiency and efficiency potential of the MoM-SA materials and approach (mean score out of 4)

\begin{tabular}{|c|c|}
\hline 1. Learner assessment of the SUPPORT of the materials and approach & $\begin{array}{c}\text { Mean score } \\
\text { (out of } 4 \text { ) }\end{array}$ \\
\hline The introduction in the general course book helped me to use the materials & 3.03 \\
\hline $\begin{array}{l}\text { The use of English in the general course book helped me to use the } \\
\text { materials }\end{array}$ & 3.10 \\
\hline The use of English in the grammar book helped me to use the materials & 3.32 \\
\hline The online translations helped me to understand the scenarios & 3.12 \\
\hline The teacher helped me to become a better learner & 3.80 \\
\hline The teacher helped me to communicate better & 3.93 \\
\hline TOTAL: & 3.41 \\
\hline \multicolumn{2}{|l|}{ 2. Learner assessment of the IMPACT of the materials and approach } \\
\hline The MoM online material supported and reinforced what I learned in class & 3.31 \\
\hline The exercises on Webstudies reinforced what I learned in class & 3.29 \\
\hline My ability to understand spoken Afrikaans has improved & 3.76 \\
\hline My ability to use spoken Afrikaans has improved & 3.16 \\
\hline My Afrikaans vocabulary has improved & 3.72 \\
\hline My Afrikaans medical vocabulary has improved & 3.23 \\
\hline My understanding of the language structures in Afrikaans has improved & 3.00 \\
\hline MoM has improved my communication skills in Afrikaans & 2.93 \\
\hline I feel more comfortable with medical Afrikaans & 2.89 \\
\hline TOTAL: & 3.23 \\
\hline \multicolumn{2}{|l|}{ 3. Learner assessment of the RELEVANCE of the materials and approach } \\
\hline The communication scenarios are relevant to my needs & 3.41 \\
\hline The wordmaps are relevant to my needs & 3.24 \\
\hline The drawings are relevant to my needs & 3.27 \\
\hline The exercises are relevant to my needs & 3.41 \\
\hline The grammar book is relevant to my needs & 3.36 \\
\hline $\begin{array}{l}\text { Online MoM is accessible with the equipment that I have available } \\
\text { (desktop/smartphone) }\end{array}$ & 2.89 \\
\hline The online interactive wordmaps are relevant to my needs & 3.00 \\
\hline TOTAL: & 3.24 \\
\hline \multicolumn{2}{|l|}{ 4. Learner assessment of the SUFFICIENCY of the materials and approach } \\
\hline The scenarios are sufficient to improve my communication skills & 3.04 \\
\hline The wordmaps are sufficient to improve my communication skills & 2.86 \\
\hline The grammar book is sufficient to improve my communication skills & 3.07 \\
\hline $\begin{array}{l}\text { The online pronunciation is sufficient to improve my communication } \\
\text { skills }\end{array}$ & 3.11 \\
\hline TOTAL: & 3.04 \\
\hline
\end{tabular}




\begin{tabular}{|l|c|}
\hline 5. Learner assessment of the EFFICIENCY of the materials and approach \\
\hline The general course book is easy to use & 2.97 \\
\hline The layout and structure of the general course book are clear & 3.11 \\
\hline The grammar book is easy to use & 2.80 \\
\hline The layout and structure of the grammar book are clear & 3.03 \\
\hline The MoM online material is easy to use & 2.63 \\
\hline The structure of MoM online is clear & 3.00 \\
\hline The navigation of MoM online is clear & 2.82 \\
\hline The voice-overs in MoM online are clear and easy to understand & 3.41 \\
\hline TOTAL: & $\mathbf{2 . 9 7}$ \\
\hline
\end{tabular}

The evaluation criterion of support (see Table 4, part 1) scores highly $(\mathrm{M}=3.41)$ due to a very positive evaluation of the lecturer: students indicated that they highly appreciated their lecturer's help to communicate better and become a better learner. The use of English in the grammar book is experienced as a helpline, whereas people seemed slightly less convinced of the online support. The lowest score for learning support was allocated to the course book's introduction. Since the lecturer did not go through the helplines systematically in class, we do not know whether students used what was provided as such.

Impact and relevance (numbers 2 and 3 respectively in Table 4) also have high total scores (M $=3.23$ and $\mathrm{M}=3.24$, respectively), with especially high scores for the ability to understand spoken Afrikaans and the knowledge of vocabulary (a receptive and productive skill). The relatively low scores for improved communication skills in general $(\mathrm{M}=2.93)$ and medical Afrikaans in particular $(\mathrm{M}=2.89)$ can be explained by the fact that these categories refer to a broad productive skill and a professional context. The ability of the MoM-SA online materials and the assignments on Webstudies-Blackboard to support and reinforce what was learned in class is high.

The communication scenarios, exercises and grammar book are regarded as highly relevant to the learners' needs. Drawings and wordmaps also score well for relevance, but the availability of equipment to access MoM scores relatively low. Students may not have (regular) access to computers. Even though most of them have smartphones, it showed in the follow-up discussions that most of them were not aware of MoM-SA as a mobile application.

Sufficiency (number 4 in Table 4 ) has a score of $M=3.04$. Learners are aware of the learning that lies ahead, even though their language learning skills may benefit from some exposure to new learning routes and routines and can be improved. Students are most positive on the sufficiency of the pronunciation tool. It has to be observed that five out of 30 learners $(16 \%)$ react negatively on each of the sufficiency statements.

In comparison to the other evaluation criteria, there is a lower overall score on efficiency (number 5 in Table 4) $(\mathrm{M}=2.97)$, mainly due to low scores on the ease of use and navigation of the online materials (with $40 \%$ and $33 \%$ of learners, respectively, scoring on the negative side of the scale). The fact that only one session was available to introduce the online MoMSA materials may explain this score.

The learners' narrative comments range from problems they have experienced when using the 
communication learning tool to any positive and negative aspects and improvements they would like to suggest. The comments reinforce the quantitative findings and underscore the fact that students rate the course materials and the programme highly. All in all, they would like more hours of teaching over a longer period of time and more guidance in using the online tool. The comments suggest that students need more help to understand online navigation (where are the translations?), online learning (how do you use mindmaps and, in particular, wordmaps?), using online and mobile tools (how can I study my own speech production with the video materials?) and understanding computer settings (how do I switch on the voice-overs and the sound in general on my PC?). However, comments did include appreciation that "you can work independently and you get immediate feedback".

Some students point out the need for more translations in the course book. The fact that the grammar book has three-line summaries for every grammar entry (which was very positively evaluated) may have supported this reaction. Moreover, the students are (false) beginners in Afrikaans and they are familiar with translation as a learning support and learning routine. Nevertheless, some students see the potential of the MoM-SA approach and one student commented that "the use of Afrikaans without English translations (in instructions) made the website look more intimidating than it is". Another student commented that the course book "was concise but had all the information that was relevant and important". One student summed it up by saying that "everything was systematically planned and fell into place; that I liked and we had multiple resources to refer to". A final comment from a student was: "I am grateful for such a course because it not only gets you into the mode of speaking Afrikaans but it combats fear of speaking out loud and reinstates one's self esteem". It is striking that all students appear to enjoy the learning and called the course a "great learning experience". As one student put it, "I personally gained a lot. I can now speak and understand a bit of Afrikaans. I am very excited about that".

In sum, the narrative component of the evaluation supports the fact that students recognise the scenarios as part of their vocational training and professional contexts and these students acknowledge MoM-SA as a language support guide: "MoM-SA helps to improve my communication not only in terms of medicine but with peers and educators alike". Students feel like they are taken seriously as pre-professionals and also feel intellectually stimulated because they have to engage in functional language use. In the words of one student, "it helped me get to understand what I really need to know regarding medicine". The fact that they are made aware of the professional communication content is, in itself, experienced as motivating. However, students are not the only stakeholders in a programme; it is also important to consider instructors' experiences.

\subsection{The lecturer's experience}

As the lecturer was one of the important stakeholders in the new programme, she kept a logbook during the course and noted down her observations about the course and its students. Since she was positively evaluated, we felt that looking into her impressions of this pilot project ${ }^{10}$ may help us to better understand these learners' needs.

\footnotetext{
${ }^{10}$ The role of the teacher in the blended learning context is the topic of a follow-up study.
} 
The lecturer's notes indicated that students were motivated to learn and voiced a need to communicate in Afrikaans within a professional context. Consequently, the students were eager to participate in learning activities in class and spontaneously asked questions related to vocabulary and grammar.

Although the course only had 20 hours of contact time, the online course content and activities provided extensive learning opportunities that far exceeded these 20 hours. Due to the systematic structure and increasing complexity of the course materials, as well as the fact that the course book is logically integrated with the online materials, it was easy for the lecturer to refer students to both online and course book material when they expressed their individual needs. In this way, learner-centred interaction was possible. For example, within a role-play situation, the lecturer could support her response to questions on the use of pronouns by referring students to further online materials and activities. For homework, students had to reflect on their own experiences which were then discussed in class. It was thus easy to bring real-life scenarios into the class and integrate them with grammatical and structural content. The lecturer noted that the dynamic and unpredictable nature of the lessons also required her to be well prepared and to have a sound knowledge of the course's learning content.

As mentioned above, the group of students had a fairly wide range of abilities and, on the language placement tests, scored between $0 \%$ and $27 \%$ for Afrikaans and between $32 \%$ and 93\% for English. Thus, several students struggled to express themselves not only in Afrikaans, but also in English - the latter being their chosen language of instruction. The following is an email received by the lecturer which illustrates this (i.e. a student's limited knowledge of English which was his/her medium of instruction):

Dear C, how have you been nice to hear from you, I would like to ask you something if you can help me with, you know that I am straggling with the language so please I am looking for the English course or someone who can teach me scientific language how to write report. kind regards.

Several studies have shown that bilingualism has a positive effect on third language learning (Molnár 2010) and, indeed, the students who were more proficient in English showed a higher learning gain in Afrikaans than those who were less proficient in English.

The fact that the class consisted of first-year students entering tertiary education explains why time had to be allocated to address general academic literacy issues (such as formal academic communication) and computer literacy (such as working with the university's education software) which would not have been necessary had the students taken the course at a later stage in their academic career (the students took part in an academic writing and critical thinking course towards the end of the second semester of their first year).

Other challenges included the fact that the course books were not available in the first lesson. Students were not all computer literate and were consequently hesitant to use MoM online. There was no internet connection in class and it was not possible for the lecturer to show students how to access MoM online. 


\section{Recommendations}

The MoM-SA course was a pilot project with a small number of participants and was the lecturer's first opportunity to teach this specific course with this specific approach. Taking this into account, in addition to the results from the course evaluation and keeping in mind that innovation in linguistic design happens "in an incremental [rather] than in a spectacular fashion" (Weideman 2013), several recommendations for the next teaching period can be outlined. Firstly, future courses should take time to introduce online language learning. In order to ensure optimal accessibility of the materials and learner autonomy ${ }^{11}$, students should first and foremost be given appropriate support in becoming computer literate and aware of how to use the programme's online materials.

Secondly, paper-based learning should explicitly be introduced into future courses. From the first lesson onwards students should familiarise themselves with the course's design and define their own objectives and targets, as well as measure their own progress for every unit.

Thirdly, future courses should gradually introduce individualised language learning. With this support, students should become more aware of their own learning strategies and preferences as well as their needs, wants and desires ${ }^{12}$.

Finally, future courses should systematically introduce existing helplines. Learners should be introduced to both traditional support tools as well as online tools in different ways. For instance, where to find and how to use the translations of learning content, how to use the pronunciation videos and interactive wordmaps, how to engage in community learning, and where to find technical support should be explained to them.

Ideally, following these recommendations will result in a more holistic learning approach where students are able to reflect on their learning routines and are coached into using contextualisation instead of translation as a communication strategy. Students could also be invited to prepare the scenarios by making use of the online audio, translation and practice support before coming to class. This would ensure that the lecturer is able to play a more supportive role during discussions, thereby reinforcing the learned content whilst helping students in becoming autonomous learners.

Based on the recommendations above, there are several directions to take for future research. The present study will first be replicated with a larger group to see whether meeting the above recommendations will have an effect on learning gain and well-being. The blended learning approach will also be studied with more mature medical students, i.e. the Cuban-trained SA medical students during their intensive reintegration programme at the beginning of their sixth year, to see what effects it may have. Linguistically, it might be worth considering the students' requests for more translations (possibly in more indigenous languages) and to fully exploit the multilingual character of the support system. However, it may also be valuable to make a conscious effort to introduce a contextualisation approach and help students to overcome the immediate urge for translations. Either way, the programme will support the university's multilingual policy.

\footnotetext{
${ }^{11}$ The role of the teacher in this learning environment will be focused on in a follow-up study.

${ }^{12} \mathrm{We}$ will report on students' online logs and learning preferences as part of a follow-up study.
} 


\section{Conclusion}

This paper has addressed how the existing online communication tool, MoM, was turned into a dynamic and flexible teaching and learning tool called MoM-SA which was adapted to the needs of the South African vocational learners. The adaptation process and pilot have been outlined and showed how the materials were adapted to the South African medical context with the aim of providing optimal communication support, as well as illustrating how blended learning can be introduced to balance contact teaching and online learning. Further, we have discussed how the stakeholders (lecturer and medical students) evaluated MoM-SA's success in terms of usability (support, relevance, impact, sufficiency and efficiency) and we have linked these findings to the different course components, drawing on the perceptions of the learners (usability questionnaire with narrative comments at end of course), the experience of the lecturer (logbook), and pre- and post-test results. Last but not least, we have formulated some recommendations for how this project may be carried forward.

Not only did the pilot group show consistent learning gain, the learners also experienced an improvement in receptive and productive ability in both general and professional domains. They liked the materials, the content and the approach, and positively evaluated the relevance of these elements. Students experienced their learning to be a continuous but pleasant effort despite some issues with computer literacy (which future versions of the course should attempt to address).

A true multilingual South African society expects medical professionals to not only manage a second language, but also a third or fourth one. A true multicultural South African society expects medical professionals to manage culturally-determined ideas, concerns and expectations. As a communication support system, MoM-SA is meant to ultimately foster and enrich a multilingual and multicultural professional environment. Thanks to its high face validity, MoM-SA may be well on its way to doing so.

\section{References}

Brown, J.D. 1995. The elements of language curriculum. Boston, Massachusetts: Heinle and Heinle Publishers.

Campion, P.D., N.M. Butler and A.D. Cox 1992. Principal agendas of doctors and patients in general practice consultations. Journal of Family Practice 9: 181-190.

Carroll, J.B. and S. Sapon. 2002. Modern Language Aptitude Test: Manual 2002 Edition. Bethesda, MD: Second Language Testing, Inc.

Epstein, R.M. 2000. The science of patient-centred care. Journal of Family Practice 49: 805807.

Gasiorek, J. and K. Van de Poel. 2012. Divergent perspectives on language-discordant mobile medical professionals' communication with colleagues: an exploratory study. Journal of Applied Communication Research 40(4): 368-383. 
Graham, R.G. 2006. Blended Learning Systems - Definition, Current Trends, and Future Directions. In C.J. Bonk and R.G. Graham (eds.) The handbook of blended learning. Global perspectives, local designs. San Francisco: Pfeiffer. pp. 3-21.

Hewett, D.G., B.M. Watson, C. Gallois, M. Ward and B.A. Leggett. 2009. Communication in medical records: Intergroup language and patient care. Journal of Language and Social Psychology 28: 119-138.

KZN Department of Health, South Africa. 2013. Available online: http://www.kznhealth.gov.za/Clinical_Associate/clinical_associates.pdf (Accessed June 2013).

Levenstein, J.H., J. Belle Brown, W.W. Weston, M. Stewart, E.C. McCracken and I. McWhinney. 1989. Patient-centred clinical interviewing. In M. Stewart and D. Roter (eds.) Communicating with medical patients. Newbury Park: Sage Publications Inc.

LHUP, Lock Haven University. Learning Gain Scores Calculation. Available online: http://www.lhup.edu/swillia6/courses/math316/documents/TWS documents/TWS Factor5 le arning_gain_worksheet.pdf (Accessed June 2013).

Medics on the Move (MoM). Language solutions where and when you need them. Available online: http://www.medicsmove.eu (Accessed 4 July 2013).

Mishler, E.G. 1984. The discourse of medicine: Dialectics of medical interviews. Norwood: Ablex.

Molnár, T. 2010. Second language versus third language vocabulary acquisition: A comparison of the English lexical competence of monolingual and bilingual students. University of Szeged. Toronto Working Papers in Linguistics 33.

Riel, M. 1998. Education in the 21st century: Just-in-time learning or learning communities. Conference paper in Education and the Arab World: Challenges of the Next Millenium. Abu Dhabi: Centre for Strategic Studies and Research.

Silverman, J.D., S.M. Kurtz and J. Draper. 2005. Skills for communicating with patients. Oxford/San Francisco: Radcliffe Publishing.

Stellenbosch University. 2004. Taalbeleid van die Universiteit Stellenbosch. Available online: http://www.sun.ac.za/english/Documents/Language/taalbeleid2004.pdf (Accessed 21 July 2013).

Stellenbosch University. 2010. Taalplan van die Universiteit Stellenbosch. Available online: http://www.sun.ac.za/english/Documents/Language/Taalplan2010.pdf (Accessed 21 July 2013).

Stewart, M.A. 1995. Effective physician-patient communication and health outcomes: A review. Canadian Medical Association Journal 15(9): 1423-1433. 
Stewart, M., J. Belle Brown, W.W. Weston, I.R. McWhinney, C.L. McWilliam and T.R. Freeman. 2003. Patient-centred medicine: Transforming the clinical method. Thousand Oaks: Sage.

Tate, P. 2007. The doctor's communication handbook. Oxford: Radcliffe Publishing.

Universiteit Stellenbosch, Fakulteit Geneeskunde en Gesondheidswetenskappe. 2008. Taalplan. Available online: http://www.sun.ac.za/afrikaans/.../BeleidVoorgraads/FGW_Taalplan.pdf (Accessed October 2012).

Van de Poel, K. 1995. Overlevingsnederlands: De talige behoeften van uitwisselingsstudenten. Nederlands van $\mathrm{Nu}$ 42(5): 99-102.

Van de Poel, K. 2011. From multidimensional needs to language training for mobile professionals: An interdisciplinary approach. In S. De Wannemacker, G. Clarebout and P. De Causmaecker (eds.) Interdisciplinary approaches to adaptive learning: A look at the neighbours. Berlin/Heidelberg: Springer. pp. 70-84.

Van de Poel, K. 2013. Taalontwikkeling vir mediese studente. Language development for medical students. Bloemfontein: MoM-ICELDA.

Van de Poel, K. and T. Brunfaut. 2010. Medical communication in L1 and L2 contexts: Comparative modification analysis. Intercultural Pragmatics 7(1): 103-130.

Van de Poel, K. and Gasiorek, J. (in press). "We feel stupid and we shouldn't." Towards developing a support system for Cuban-trained medical students. Per Linguam.

Van de Poel, K., K. Seberechts and C. Fourie. 2013. Medics on the Move South Africa - Access to medical words. Studies in Self-Access Learning 4(4): 339-352 .

Van de Poel, K., E. Vanagt, U. Schrimpf and J. Gasiorek. 2013. Communication skills for foreign and mobile medical professionals. Berlin/Heidelberg: Springer.

Van Dyk, T. and K. Van de Poel. 2013. Medics on the Move. Basiese Afrikaanse grammatika. Bloemfontein: MoM-ICELDA.

Watson, B.M., D.G. Hewett and C. Gallois. 2012. Intergroup communication and health care. In H. Giles (ed.) Handbook of intergroup communication. New York: Routledge. pp. 293-305.

Weideman, A.J. 2003. Assessing and developing academic literacy. Per Linguam 19 (1 and 2): $55-65$.

Weideman, A.J. 2013. Innovation and reciprocity in applied linguistics. Keynote address at the SAALT/SAALA/LSSA conference, 1-4 July 2013 University of Stellenbosch, Stellenbosch. 